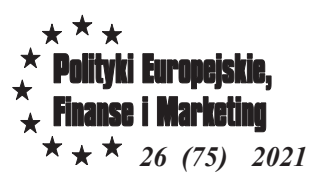

DOI 10.22630/PEFIM.2021.26.75.11

Received: 16.07 .2021

Accepted: 20.11.2021

Nadia Davidenko

National University of Life and Environmental Sciences of Ukraine, Kyiv

Natalia Wasilewska

The Jan Kochanowski University of Kielce

\title{
ESTIMATION OF FINANCIAL STABILITY OF AGRARIAN ENTERPRISES IN UKRAINE
}

In this paper the system of factors influencing the formation of financial solvency was investigated, the financial sustainability of agricultural enterprises of Ukraine was evaluated, and an approach was developed to define and help ensure the financial sustainability of enterprises in the face of contemporary economic and market challenges. According to the research, the main principles for maintaining financial sustainability are: responsiveness to internal and external changes; governance systems; risk management; analysis of financial ratios; real assessment of the financial solvency of the enterprise; integration with the overall management system; orientation towards achieving the strategic goals of the enterprise; use of qualitative methods to inform financial decisions in the face of uncertainty and risk.

Keywords: financial equilibrium, financial stability, enterprise financing, the mechanism of financial stability provision, risk, uncertainty.

JEL Codes: O13, O16

\section{Introduction}

Developing the agro-industrial sector into one of the most important sectors of the national economy is can be a way to increase national economic capacity and competitiveness. But the current state of Ukraine's economy is unsatisfactory and is characterized by rather complex economic conditions. The activities of agribusiness enterprises are being carried out under conditions of uncertainty, such as: the slow development of scientific progress; an unstable political situation; Russian military actions in the east of Ukraine; the increase of market competition; the intensification of globalization processes; and the scarcity of information. Under such conditions, a modern farming system requires enterprises to improve production efficiency and the competitiveness of products and services, as well as to monitor economic performance in a timely manner. The volatility of the external environment has a significant impact on businesses; their economic situation and their stable development. The problem of ensuring financial sustainability is therefore very relevant in today's business environment.

The aim of the research is to comprehensively investigate the financial sustainability of agricultural enterprises in Ukraine and to substantiate the method of its evaluation. 


\section{Literature review}

The issue of financial sustainability has figured prominently in the writings of many scholars. A study of economic literature revealed the lack of a unified approach to defining the category of "financial stability". An analysis of different interpretations of this concept shows the presence of different views on the economic content of financial stability depending on the goals and objectives of the study in question.

Thus, some scholars consider financial stability in the context of a company's independence from external sources of funding. From this definition it follows that a financially stable enterprise is one which finances activities only at its own expense. But the use of only equity significantly limits the efficiency and options of economic activity for an enterprise.

The Ukrainian researcher N. Tarasenko places financial stability on conforming activity to the generalizing ratios which characterize the economic components of stability: maintaining sufficient financial continuity for the main types of activities. L. Sokolova (1996), in considering financial stability, stated that a financial condition is considered stable if the enterprise achieves the necessary parameters in the areas of profitability, the availability of its own financial resources; rational allocation of noncurrent and current assets, solvency and liquidity.

However, it is incorrect to determine financial stability only by the compliance of an enterprise's activity with the normative generalizing ratios, because they are only a reference point and often have different calculation algorithms and normative values.

Most researchers rightly define financial stability as one of the characteristics of the financial condition of the enterprise. I. Blank determined financial stability as a characteristic which is provided by a high share of equity in the total amount of financial resources used (Blank, 1999). In a broad sense, financial stability can be interpreted as the ability of the enterprise to function close to the financial and economic equilibrium under the conditions of constant external and internal influences of factors. In a narrower sense, the financial stability of an enterprise is a financial and economic condition of the organization, in which it is liquid, solvent and has sufficient funds. M. Kreynina stated that financial stability is provided by a sufficient share of equity in the sources of funding (Kreynina, 2021). At the same time, a sufficient share of equity means that the loan sources of financing are used to ensure their full and timely repayment. From this point of view, short-term liabilities in total should not exceed the value of liquid assets in terms of inventories and work in progress.

Another author understands financial stability as the state of financial resources of an enterprise, their structure and level of maneuvering, which ensures financial independence and development on the basis of profit growth and capital, provided by an allowable level of risk (Kovalenko, 2005).

Research on the analysis and evaluation of the financial soundness of an enterprise dates back to the 1960s. E. Altman and U. Beaver have undertaken financial evaluations aimed at the financial stability of enterprises (Altman, 1968). The problem of financial sustainability has been studied in the works of such known scientists as U. Briggem and L. Gapensky, J. Van Horn, B. Kallus and others whose works are devoted to financial analysis and management. With regard to Ukrainian researchers, an analysis of recent research and publications leads to the conclusion that different authors suggest 
alternative ways of measuring the sustainability of economic systems that not only differ from each other in economic content but often quite distort the original meaning of the concept of sustainability (Goncharenko, 2010).

In view of the excessive imbalance of the methodological bases, V. Podolskaya and A. Orzhinska take the position that it is necessary to develop the methodology, and fundamentally new approaches to the analysis of financial sustainability, including studies of the efficiency of activities and the threat of bankruptcy (Podolskaya and Orzhinska, 2009). A. Zhuravleveva, researching problematic aspects of objectively establishing the financial stability of modern economic subjects, notes that one of the most important economic problems is the definition of financial stability (Zhuravleva, 2009). Taking into account a number of problematic aspects in this area, A. Pacula notes that, in general, questions of operational analysis and basic ratios of activity of economic entities remain relevant (Pacula, 2010). As a result of literature review on this subject, it is apparent a lot of important questions still need to be investigated. The nature of financial sustainability is not clearly defined, and the features and the methods of its measurement are not fully disclosed. The influence financial stability on the aspects of an enterprise's financial health remain insufficiently studied in the literature.

\section{Research methodology}

Currently in Ukrainian practice, the fundamental principle of enterprise management regarding any type of economic activities, in particular financial management, is largely based on ratios that have financial stability and financial condition as the starting point of its development (Kondrat, 2017).

Determining the financial stability of an enterprise has important scientific and practical significance. It is an objective indicator of the level of economic and financial activity of agricultural enterprises.

The financial sustainability of an enterprise is one of the most important features of its operations and financial well-being. It describes the outcome of current, investment and financial development, provides necessary information for investors, and reflects the ability of an enterprise to meet its debts and obligations and to build economic capacity. In the face of current challenges, financial sustainability is the main condition for existence and the basis for the stability of the enterprise. Financial stability characterizes the level of financial independence of an enterprise in terms of ownership of its property and its use (Bagatskaya, Govorushko, Sheremet, 2014).

To ensure the sustainable development of agribusiness, it is important to draw attention to the harmonization of selected ratios of companies' financial sustainability, which are calculated as the ratio of individual parts of a whole (Dorofeyev, Voronina, Toryanik, 2019). If an agricultural enterprise has an insufficient level of financial sustainability (unstable or crisis financial condition) it can lead to insolvency or bankruptcy (Lesyuk, 2020). If an enterprise is financially sustainable, it has an advantage over other businesses in attracting investment, obtaining credit, selecting suppliers and selecting skilled personnel. Moreover, it does not conflict with the State and society, since it pays taxes on time to the budget, makes social contributions to the Pension Fund and other contributions, pays salaries of employees, pays dividends to 
shareholders, and guarantees to banks the repayment of loans and the payment of interest.

Today there are various methodological approaches to assessing the financial sustainability of agricultural enterprises, and a variety of ratios that do not reflect a complete and objective assessment of production and economic activities of agricultural enterprises. Therefore, the establishment of a single system of ratios for an in-depth assessment of the financial status of agricultural enterprises will contribute to the objective analysis of their production and economic activities. The monitoring of financial sustainability ratios shows the current state of the financial system and allows for the rapid monitoring of all changes. Ratios are part of a large information block that is used to monitor financial stability (Rodica, Alexandru, Angela, 2014). The financial sustainability of an agricultural enterprise involves the use of ratios that reflect various aspects of the enterprise's production and management. The financial stability assessment should be able to determine whether an enterprise has managed its financial resources properly during the period.

It is important that the state of financial resources meets market conditions and the needs of the enterprise, because insufficient financial stability can lead to a lack of funds for further development, while excessive funds can hinder development, burdening the company's costs with excessive reserves (Kruppelitskaya, Yushko, 2013). The financial sustainability of an enterprise depends on the optimal structure of the sources of capital (the ratio of equity to debt), the optimal structure of assets (current and noncurrent assets), as well as the balance of assets and liabilities. Therefore, there is a need to assess the structure of an enterprise's sources and to assess the degree of financial sustainability and financial risk (Lesyuk, 2020).

Three sets of ratios are useful for assessing the financial sustainability of agricultural enterprises: ratios of the structure, capital cost, and other ratios related to capital.

The use of ratios in assessing financial sustainability allows the identification of specific areas for improvement of an enterprise's performance. The first group of ratios of the structure and value of the sources of capital of agricultural enterprises describes the relationship between the division of liabilities: equity; long-term liabilities and security; current liabilities and security, as well as liabilities related to non-current assets held for sale.

The second and the third groups of ratios of the capital condition of agricultural enterprises describes the relationship between the divisions and items of on the balance sheet, namely: noncurrent and current assets, liabilities, equity and liabilities, as well as liabilities related to non-current assets held for sale.

In practice, financial ratios are used to analyse the financial stability of an enterprise and are calculated with respect to the absolute values of the assets and liability. Their comparison with critical values allows to determine the level of financial stability of an enterprise (Kurganski, 2011).

In our opinion, the main elements of financial stability of an enterprise are: (Figure 1): solvency; liquidity; profitability; financial activity; creditworthiness.

In general, the essence of these definitions can not be considered contradictory because they differ in the degree of detail and characterize different aspects of the 
category, which determines certain methodological approaches to assessing financial stability.

It should be noted that in the financial and economic analysis there is a division of ratios into ratios that characterize the assessment of the financial stability of an enterprise, as well as ratios that aim to assess the management of financial stability. This is because the state of financial stability is assessed in static terms and is characterized by ratios for a specific date, as such ratios are normalized. The state of management of financial stability of enterprises can be assessed only by dynamic ratios.

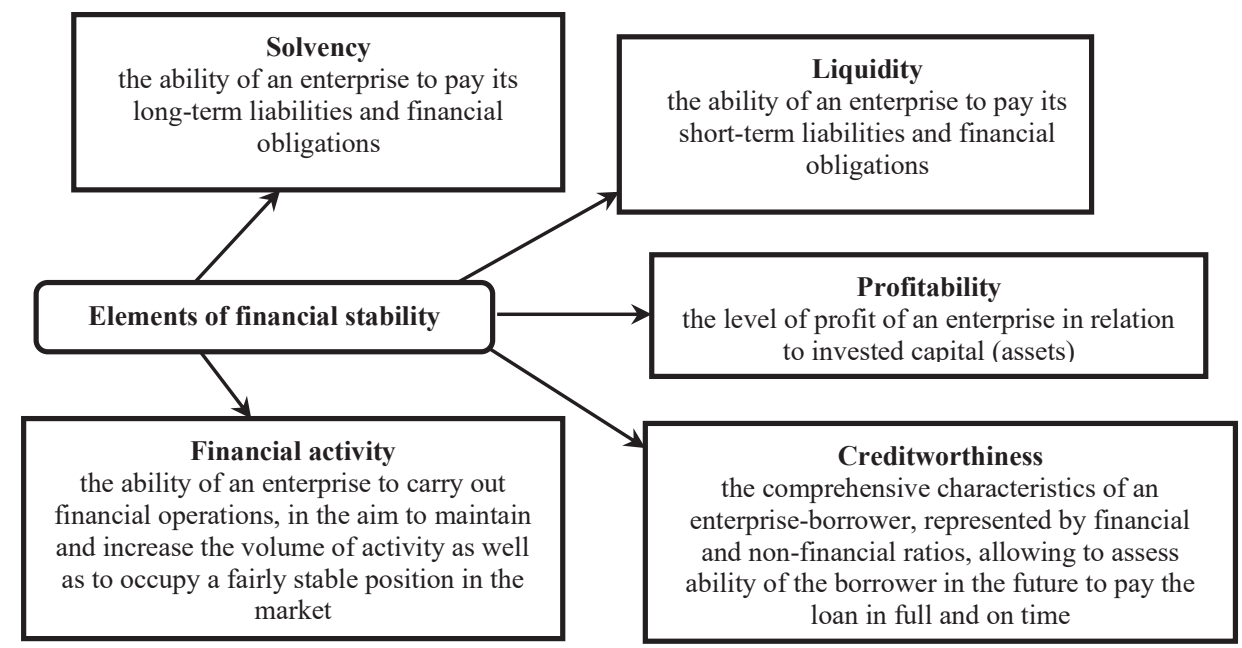

Figure 1. The main features of the financial stability of an enterprise

Source: compiled by the authors based on literature review.

Analysis of the financial stability of an enterprise using relative ratios allows to identify the nature of the ratio of equity and debt capital, the rate of accumulation of equity as a result of current and financial activities, mobile and immobilized assets, and the level of working capital.

\section{Results and Discussion}

In the conditions of deep quantitative and qualitative, organizational and managerial changes as well as contemporary challenges in Ukraine, one of the prerequisites for sustainable development of economic activities of enterprises is to ensure that they are able to operate sustainably under the conditions of disturbed external influences.

The concept of stability is one of the basic concepts of mathematical modeling and is closely related to the idea of invariance. The following stages are distinguished:

- forecasting future targets;

- determination of an enterprise's overall financial resource needs;

- forecasting the structure of funding sources;

- justification of the chosen option from all possible solutions in order to achieve the planned results of an enterprise's activities. 
The financial sustainability of an enterprise is the stable availability of financial resources sufficient to meet financial obligations, the ability of an enterprise to finance its economic and productive activities, a balance between positive and negative cash flows, an aggregate assessment of the level of its solvency, liquidity, profitability, creditworthiness and other ratios, as well as a prerequisite for the enterprise to achieve long-term financial equilibrium (Davydenko, 2009). We believe that, in the current economic climate, the liquidity and solvency of agricultural enterprises are among the most important ratios of the financial sustainability of agricultural enterprises.

During the period from 2015 to 2019 there was a slight increase of Ukrainian agricultural enterprises' solvency ratio (from 0.05 to 0.06 ), but despite a slight increase of this ratio it does not correspond to the norm value ( $\geq 0.2$ or more than $20 \%$ ). As a result, agricultural enterprises in Ukraine had insufficient financial solvency $(5.3 \%$ in 2015 , and $6.1 \%$ in 2019) (Table 1).

Table 1. The liquidity and solvency ratios of Ukrainian agricultural enterprises

\begin{tabular}{|c|c|c|c|c|c|c|}
\hline \multirow{2}{*}{ Ratios } & \multicolumn{5}{|c|}{ Years } & \multirow{2}{*}{$\begin{array}{c}2019 \text { comparison } \\
\text { with } 2015,(+/-)\end{array}$} \\
\hline & 2015 & 2016 & 2017 & 2018 & 2019 & \\
\hline Cash ratio & 0.053 & 0.019 & 0.053 & 0.057 & 0.61 & 0.008 \\
\hline Quick ratio & 1.125 & 1.032 & 1.002 & 0.896 & 0.831 & -0.294 \\
\hline Overall liquidity ratio & 1.503 & 1.191 & 1.537 & 1.563 & 1.547 & 0.044 \\
\hline Inventory coverage ratio & 3.580 & 7.421 & 2.867 & 2.325 & 2.155 & -1.425 \\
\hline Solvency ratio & 0.049 & 0.018 & 0.049 & 0.053 & 0.057 & 0.008 \\
\hline
\end{tabular}

Source: compiled by the authors based on statistical data [State Statistical Service of Ukraine, 2020]

Overall liquidity ratio of agricultural enterprises of Ukraine for 2015-2019 showed an increase from 1.50 to 1.55 , which was an indication that the enterprises had sufficient working capital and were able to repay financial obligations to creditors.

The value of the quick liquidity ratio for the period under this research shows a slight negative downward trend of 0.294 (from 1.13 to 0.83 ), but the ratio corresponds to the standard value $(\geq 0.7)$ Therefore, agricultural enterprises have a high level of calculated solvency. During the period under review, the capacity to pay had increased from 0.05 to 0.06 . The value of this coefficient is lower than the norm value $(\geq 0.1)$, which indicates an insufficient cash supply within Ukrainian agricultural enterprises.

The level of the price range of Ukrainian agricultural enterprises in fulfilling current obligations has decreased. The State should devote efforts to the reproduction and modernization of the productive and resource potential of agro-industrial production, promote the revitalization of foreign economic activities of the agricultural sector, and ensure effective demand for agricultural products.

The financial sustainability of agricultural enterprises reflects the efficiency of their use of equity capital and the ability to attract external financing and to pay their obligations in a timely manner. The estimation of the structure and value of capital of agricultural enterprises in Ukraine shows a significant financial dependence on creditors (Table 2).

For example, the ratio of equity concentration indicates that at the end of 2019 , equity to total assets was $50.7 \%$; this is an increase of 0.11 compared to 2015 . The financial dependency ratio for the study period fell from 2.49 in 2015 to 1.97 in 2019 , indicating a decrease in the share of borrowed funds in financing Ukrainian agricultural enterprises and an increase in their financial independence. The debt to equity ratio 
decreased from 0.56 in 2015 to 0.50 in 2019. Despite this, Ukrainian agricultural enterprises have a high level of financial dependence on creditors.

The increase in the level of financial stability of agricultural enterprises in Ukraine is evidenced by the value of the financial stability ratio, which increased from 0.50 in 2015 to 0.60 in 2019. 1 UAH of equity covered $1.49 \mathrm{UAH}$ of borrowed capital and 0.97 $\mathrm{UAH}$ in 2019. Accordingly, the value of the debt to equity ratio shows that equity exceeded debt capital by 0.7 times in 2015, and by 1 time in 2019 .

Table 2. The structure and value of capital ratios of Ukrainian agricultural enterprises

\begin{tabular}{|l|r|r|r|r|r|r|}
\hline \multirow{2}{*}{ Ratios } & \multicolumn{2}{c|}{ Years } & \multicolumn{2}{c|}{$\begin{array}{c}2019 \\
\text { comparison } \\
\text { with 2015, } \\
(+/-)\end{array}$} \\
\cline { 2 - 7 } & 2015 & 2016 & 2017 & 2018 & 2019 & 0.11 \\
\hline Capital concentration ratio & 0.40 & 0.24 & 0.48 & 0.49 & 0.51 & -0.52 \\
\hline Financial dependence ratio & 2.49 & 4.16 & 2.09 & 2.04 & 1.97 & 0.10 \\
\hline Financial stability ratio & 0.50 & 0.28 & 0.54 & 0.58 & 0.60 & -0.11 \\
\hline Debt concentration ratio & 0.60 & 0.76 & 0.52 & 0.51 & 0.49 & -0.52 \\
\hline Leverage ratio & 1.49 & 3.16 & 1.10 & 1.04 & 0.97 & 0.36 \\
\hline Debt to equity ratio & 0.67 & 0.32 & 0.92 & 0.97 & 1.03 & -0.05 \\
\hline Long-term leverage ratio & 0.20 & 0.14 & 0.12 & 0.15 & 0.15 & 0.05 \\
\hline $\begin{array}{l}\text { Financial independence ratio of } \\
\text { capitalized sources }\end{array}$ & 0.80 & 0.86 & 0.88 & 0.85 & 0.85 & 0.01 \\
\hline Long-term liabilities ratio & 0.17 & 0.05 & 0.12 & 0.16 & 0.18 & -0.01 \\
\hline Current liabilities ratio & 0.83 & 0.95 & 0.88 & 0.84 & 0.82 & -0.10 \\
\hline Current debt ratio & 0.50 & 0.72 & 0.46 & 0.43 & 0.40 & 0.01 \\
\hline
\end{tabular}

Source: compiled by the authors based on statistical data [State Statistical Service of Ukraine 2020]

In 2015-2019, the long-term borrowing ratio decreased from 0.2 in 2015 to 0.15 in 2019. This indicates a decrease in the dependence of Ukrainian agricultural enterprises on long-term external sources of financing. The reduction of the current debt ratio from 0.50 in 2015 to 0.40 in 2019 (which reflects the share of short-term debt of Ukrainian agricultural enterprises) also has a positive impact on the financial sustainability of Ukrainian agricultural enterprises.

The assessment of the assets of Ukrainian agricultural enterprises shows an increase in the value of the property and a sufficient level of financial stability (Table 3).

Table 3. The capital ratios of Ukrainian agricultural enterprises

\begin{tabular}{|l|r|r|r|r|r|r|}
\hline \multicolumn{1}{|c|}{ Ratios } & 2015 & 2016 & 2017 & 2018 & 2019 & $\begin{array}{c}2019 \\
\text { comparison } \\
\text { with } 2015, \\
(+/-)\end{array}$ \\
\cline { 2 - 7 } & & & & & & 0.12 \\
\hline $\begin{array}{l}\text { The ratio of the real value of fixed assets } \\
\text { in the property }\end{array}$ & 0.16 & 0.10 & 0.20 & 0.24 & 0.28 & 0.21 \\
\hline Ratio of current assets to working capital & 0.20 & 0.11 & 0.26 & 0.24 & 0.21 & 0.01 \\
\hline Inventory to working capital ratio & 0.81 & 0.85 & 0.74 & 0.55 & 0.45 & -0.36 \\
\hline Manoeuvrability ratio & 0.16 & 0.13 & 0.12 & 0.14 & 0.18 & 0.02 \\
\hline Long-term debt coverage ratio & 0.40 & 0.28 & 0.22 & 0.25 & 0.24 & -0.16 \\
\hline
\end{tabular}

Source: compiled by the authors based on statistical data [State Statistical Service of Ukraine. 2020].

So, during the period from 2015 to 2019 , there was an increase in the ratio of the real value of fixed assets in the property from 0.16 in 2015 to 0.28 in 2019, which indicates an increase in the value of the property for productive purposes of Ukrainian 
agricultural enterprises. The capital manoeuvrability ratio increased from 1.61 in 2015 to 1.34 in 2019. During the period under review, the level of equity mobility decreased by 0.27 . Despite this situation, Ukrainian agricultural enterprises have the possibility to finance their operating activity. At the end of 2019 in the structure of current assets, $20.8 \%$ were assets financed by private financial resources. Additionally, 1 UAH of inventory was financed by about $0.45 \mathrm{UAH}$ of working capital, which is an indication of the high level of self-financing of agricultural enterprises in Ukraine.

There was an increase of the manoeuvrability ratio by 0.02 . Thus, agricultural enterprises in Ukraine have a sufficient level of financial stability in terms of providing highly liquid current assets. The ratio of long-term debt coverage decreased from 0.40 in 2015 to 0.24 in 2019. This shows a decrease in the financing by external investors of capital assets and other non-current assets of Ukrainian agricultural enterprises.

The evaluation of the use of capital in agricultural enterprises in Ukraine shows an increase (renewal) of the technical condition of means of production (Table 4).

Table 4. The Capital ratios of Ukrainian agricultural enterprises

\begin{tabular}{|c|c|c|c|c|c|c|}
\hline \multirow[b]{2}{*}{ Ratios } & \multicolumn{5}{|c|}{ Years } & \multirow{2}{*}{$\begin{array}{c}2019 \\
\text { comparison } \\
\text { with } 2015,(+/- \\
)\end{array}$} \\
\hline & 2015 & 2016 & 2017 & 2018 & 2019 & \\
\hline Production equipment ratio & 0.36 & 0.22 & 0.46 & 0.53 & 0.58 & 0.22 \\
\hline Real value of fixed assets ratio & 0.16 & 0.10 & 0.20 & 0.24 & 0.28 & 0.12 \\
\hline $\begin{array}{l}\text { Ratio of current to non-current } \\
\text { assets }\end{array}$ & 3.01 & 6.03 & 2.35 & 1.99 & 1.65 & -1.36 \\
\hline Depreciation accumulation ratio & 0.42 & 0.39 & 0.38 & 0.38 & 0.38 & -0.04 \\
\hline
\end{tabular}

For example, the ratio of production equipment increased from 0.36 in 2015 to 0.58 in 2019, indicating strengthening of financial stability. The share of non-current in the total assets increased from 0.16 in 2015 to 0.28 in 2019. A decrease in the level of depreciation of fixed assets is evidenced by the value of the coefficient of depreciation of fixed assets. For example, the depreciation ratio of noncurrent assets decreased from 0.42 in 2015 to 0.38 in 2019 .

Thus, an assessment of financial sustainability of Ukrainian agricultural enterprises has been made for three groups of ratios. The structure of capital and level of financial risk are directly related to the specialization of agricultural production. It is worth noting that the combination of low level of capital turnover ratio and high level of financial risk should not be so high.

The structure of capital is a factor that directly affects the financial health of agricultural enterprises; their financial stability, long-term solvency, income and financial performance, profitability of operating activity. An evaluation of the sources of capital formation of Ukrainian agricultural enterprises was conducted (Table 5). The share of equity in total capital increased by $10.6 \%$ (from 40.1 to $50.7 \%$ ) and the share of liabilities decreased by $10.6 \%$ (from 59.9 to $49.3 \%$ ).

The growth of capitalization is the most important condition for financial security and financial stability of enterprises. Financial stability ensures a stable excess of revenues over costs, provides free maneuvering of the company's funds as well as provides the continuous production and sale process by efficient use of cash flows. In 
other words, financial stability shows the state of financial resources of an enterprise, and the distribution and use of financial resources that provides development based on the growth of profits (at an acceptable level of liquidity and solvency).

Table 5. The sources of capital formation in Ukrainian agricultural enterprises

\begin{tabular}{|c|c|c|c|c|c|c|}
\hline \multirow{2}{*}{$\begin{array}{l}\text { Sources of } \\
\text { capital } \\
\text { formation }\end{array}$} & \multicolumn{5}{|c|}{ Years } & \multirow{2}{*}{$\begin{array}{c}2019 \\
\text { comparison } \\
\text { with 2015, } \\
(+/-)\end{array}$} \\
\hline & 2015 & 2016 & 2017 & 2018 & 2019 & \\
\hline $\begin{array}{l}\text { Sources of } \\
\text { capital formation } \\
\text { - total }\end{array}$ & 685844.9 & 1537319.1 & 911614.1 & 983593.6 & 1030366.7 & 344521.8 \\
\hline Equity & 275303.8 & 369370.9 & 436337.7 & 482978.7 & 522778.7 & 247474.9 \\
\hline $\begin{array}{l}\text { Registered } \\
\text { capital }\end{array}$ & 33580.2 & 40053.5 & 43762 & 54397.9 & 55255.3 & 21675.1 \\
\hline Liabilities & 410541.1 & 1167948.2 & 475276.4 & 500614.9 & 507588.0 & 97046.9 \\
\hline $\begin{array}{l}\text { Long-term } \\
\text { liabilities }\end{array}$ & 68127.2 & 61898.2 & 59080.5 & 82254 & 92966.3 & 24839.1 \\
\hline $\begin{array}{l}\text { Current } \\
\text { liabilities }\end{array}$ & 342359 & 1105991.9 & 416146.2 & 418283.2 & 414566.5 & 72207.5 \\
\hline $\begin{array}{l}\text { Liabilities } \\
\text { related to non- } \\
\text { current assets } \\
\text { held for sale }\end{array}$ & 54.9 & 58.1 & 49.7 & 77.7 & - & 22.8 \\
\hline
\end{tabular}

The operation of Ukrainian agricultural enterprises is aimed at obtaining financial results (profits). Therefore, a timely and qualitative assessment of the efficiency of the use of available financial resources in the enterprise is important. The evaluation of the efficiency of using financial resources of agricultural enterprises provides an opportunity to assess how well agricultural enterprises use their own and borrowed capital. The main purpose of assessing the efficiency of how financial resources are used is to improve the profitability of capital and ensure the stability of the enterprise. Therefore, the next step of our research was evaluating the efficiency with which Ukrainian agricultural enterprises use financial resources (Table 6).

Financial stability depends on internal and external factors affecting the level of financial resource mobilization. In the first place, internal factors include the adequacy of profits. Financial stability depends on the range and quality of products, structure, volume and capabilities of mobilizing financial resources, reserves and achievement level of the main function of financial management.

An essential factor in an enterprise's financial stability is the optimal composition and structure of assets, as well as their efficient management and the types of products or services produced. The stability of an enterprise and the potential effectiveness of the business largely depend on the quality of management of current assets, as well as level of investment in working capital and level of cash and near-cash assets, etc. The next significant internal factor of financial stability is the composition and structure of financial resources, the right choice of tactics and strategies for managing them.

Additional funds raised in the loan capital market have a significant impact on the financial stability of enterprises. It is clear that the more an enterprise can attract funds, the greater its financial capacity. At the same time, the financial risk of the enterprise's inability to pay its creditors in full and on time is also increasing. In such 
a situation, reserves can play an important role as one of the ways to guarantee an enterprise's solvency. A financially stable entity is an economic entity that is able to cover funds that have been invested in assets (current and non-current), does not allow doubtful receivables and fulfills its obligations (Form, 2004). The basis of financial stability is the rational organization and use of working capital.

Table 6. Evaluation of the efficiency of using financial resources for Ukrainian agricultural enterprises

\begin{tabular}{|c|c|c|c|c|c|c|}
\hline \multirow[b]{2}{*}{ Ratios } & \multicolumn{5}{|c|}{ Years } & \multirow{2}{*}{$\begin{array}{c}2019 \\
\text { comparison } \\
\text { with } 2015, \\
(+/-)\end{array}$} \\
\hline & 2015 & 2016 & 2017 & 2018 & 2019 & \\
\hline Leverage ratio & 1.49 & 3.16 & 1.10 & 1.04 & 0.97 & -0.52 \\
\hline $\begin{array}{l}\text { Financial stability } \\
\text { ratio }\end{array}$ & 0.67 & 0.32 & 0.92 & 0.97 & 1.03 & 0.36 \\
\hline $\begin{array}{l}\text { Long-term } \\
\text { leverage ratio }\end{array}$ & 0.20 & 0.14 & 0.12 & 0.15 & 0.15 & -0.05 \\
\hline $\begin{array}{l}\text { Long-term } \\
\text { liabilities ratio }\end{array}$ & 0.17 & 0.05 & 0.12 & 0.16 & 0.18 & 0.01 \\
\hline $\begin{array}{l}\text { Current liabilities } \\
\text { ratio }\end{array}$ & 0.83 & 0.95 & 0.88 & 0.84 & 0.82 & -0.01 \\
\hline $\begin{array}{l}\text { Overall liquidity } \\
\text { ratio }\end{array}$ & 1.50 & 1.19 & 1.54 & 1.56 & 1.55 & 0.05 \\
\hline Solvency ratio & 0.05 & 0.02 & 0.05 & 0.05 & 0.06 & 0.01 \\
\hline Return on assets & 15.0 & 5.9 & 7.6 & 7.3 & 9.1 & -5.9 \\
\hline $\begin{array}{l}\text { Net return on } \\
\text { equity }\end{array}$ & 37.4 & 24.5 & 15.8 & 14.7 & 17.8 & -19.6 \\
\hline
\end{tabular}

Source: compiled by the authors based on statistical data [State Statistical Service of Ukraine. 2020].

The financial stability of an enterprise is closely related to its solvency. Solvency analysis of an enterprise allows to determine the its capabilities in the future. The financial activities of an enterprise involve many risks. The impact of such risks on performance is significantly increased by the instability of Ukraine's current economy. The aggressive external environment has a significant influence on the efficiency of an enterprise's activities. This situation leads to the development of ways of ensuring its ability to adapt and maintain its integrity and efficiency. The financial risks are identified as a separate group of risks, and they play the most significant role in the financial stability of enterprises.

The constant maintenance of financial stability is conditioned by the objective for each economic entity: to ensure the financial sustainability of the operation and to achieve the enterprise's main strategic goals.

\section{Conclusion}

1. Financial stability and financial security can be defined by ensuring the liquidity and solvency of an enterprise, efficient use of available financial resources, organization of internal control of the main activities of the enterprise, analysis of possible internal and external threats to economic security as well as an enterprise's level of quality management.

2. It has been established that during the period under review the level of equity mobility decreased by 0.27 , but despite this, agricultural enterprises in Ukraine have 
the capacity to finance production and other activities. It should be noted that during the period from 2015 to 2019 , the financing of current assets with equity was at the level of about $20 \%$, while at the end of 2019 the rate of financing of inventories with equity was $45 \%$.

3. During the analyzed period, the cost of capital of agricultural enterprises of Ukraine was extremely high - about $50 \%$. The share of equity in total capital increased by $11 \%$ and was on the level of $51 \%$ at the end of 2019 . Such changes indicate a positive tendency related to an increase in the financial stability of Ukrainian agrarian enterprises even under such difficult operating conditions.

4. The main objective of the financial stability analysis is to determine the ability of an agribusiness to withstand the negative impact of external and internal factors on its financial health. In the current context of the development of Ukraine's national economy, which is characterized by political and economic instability and by imperfections in legal and tax legislation, the activities of enterprises may be complicated by various crisis situations which can lead to insolvency or bankruptcy.

\section{Literature}

Altman E. (1968). Financial Ratios. Discriminant analysis and the prediction of corporate bankruptcy. Journal of Finance. № 4. P. 589-609.

Altman E., Hotchkiss E. (2006). Corporate financial distress and bankruptcy. John Wiley \& Sons. Inc. http://kadamaee.ir/payesh/books-tank/18/Altman $\% 20$ \&\%20Hotchkiss $\% 20-\% 20$ Corporate $\%$ 20Financial\%20Distress\%20and\%20Bankruptcy.\%203e\%20(2006).pdf

Activities of business entities for 2019 (2020). Statistical collection, State Statistics Service of Ukraine, 151.

Azarova A., Ruzakova O. (2010). Mathematical models and methods of assessing the financial condition of the enterprise, Vinnytsia NTU Publishing House, 172.

Bagatska K., Govorushko T., Sheremet O. (2014). Financial analysis. Kyiv, 320.

Beyer. A., Cohen. D., Lys. T. and Walther. B. (2010). The financial reporting environment: review of the recent literature. Journal of Accounting and Economics, \# 50, 296-343.

Blank I. (2004). Financial strategy of the enterprise. Elga, Nika-center, 720.

Blank I. (1999). Fundamentals of financial management, Nika-Center, 512.

Davidenko N. (2009). Financial stability of a corporate enterprise in the agricultural sector. Actual problems of economic development of the region. Scientific collection of Precarpathian National University "Vasily Stefanik", \#2, 110-116.

Dorofeev O., Voronina V., Toryanyk Y. (2019). Improving the management system of economic development of agricultural enterprises. Market infrastructure, \#36, 127-133.

Goncharenko O. (2010). Methodical aspects of optimal management of enterprise stability. Bulletin of socio-economic research: Collection of scientific works of Odessa State Economic University, \# 39, 39-43.

Kindrat O. (2017). Assessing the impact of internal and external factors on the stability of the financial and economic condition of enterprises. Current economic problems, \#1, 140-149.

Kreinina M. (2001). Financial stability of the enterprise: assessment and decision making, Financial management, \#2, 165-169.

Krupelnytska I., Yushko J. (2013). Problems of economic analysis of liquidity and solvency in modern conditions. Innovative economy, \# 8, 319-322.

Kurgan K. (2011). Financial stability of the enterprise: the use of fuzzy logic to predict bankruptcy. Modeling and information systems in economics, \#85, 185-199.

Lesyuk A. (2020). Methodological approaches to assessing financial stability of agricultural enterprises. Zeszyty Naukowe Politechniki Częstochowskiej Zarządzanie, \#38. 79-93. 
Oliynyk-Dunn O., M. Wasilewski M., Wasilewska N., Okhrimenko I. and Adamenko V. (2020). Transformation of the financing patterns of agricultural enterprises in the conditions of the financial system crisis: a case of Ukraine and the USA. Economic Annals-XXI: Volume 182, Issue 3-4, 77-89.

Patsula O. (2010). Targets of economic analysis in the context of integration and globalization processes. Scientific Bulletin of Uzhgorod University. Economics series. Special issue 29 (part 1), 254-257.

Podolskaya V., Orzhinskaya O. (2009). Comprehensive assessment of the financial stability of the enterprise. Scientific Bulletin of Poltava University of Consumer Cooperation of Ukraine, \#4 (35), 136-142.

Rodica P., Alexandru S., Angela T. (2014). The methodology of financial stability assessment of Republic of Moldova through macroeconomic ratios. Procedia Economics and Finance, Vol. 15, $383-392$.

Schinasi G. (2005). Safeguarding financial stability: theory and practice. International Monetary Fund, 89.

Sokolova L. (1996). Criteria for assessing the financial condition of enterprises. Business inform, \# $10,45-48$.

Zhuravlyova O. (2009). Financial stability of the enterprise: theory and practice. Formation of a market economy. Collection of scientific works, \#22, 523-536.

\section{Zapewnienie równowagi finansowej przedsiębiorstw rolnych na Ukrainie}

\section{Streszczenie}

W artykule zbadano system czynników wpływających na kształtowanie się wypłacalności finansowej, oceniono stabilność finansową przedsiębiorstw rolnych Ukrainy, opracowano podejście do określenia i zapewnienia stabilności finansowej przedsiębiorstw $\mathrm{w}$ obliczu współczesnych wyzwań i zagrożeń. Stwierdzono, że głównymi warunkami utrzymania stabilności finansowej są: reagowanie na zmiany wewnętrzne i zewnętrzne, systemy zarządzania, zarządzanie ryzykiem, wykorzystanie wskaźników w celu oceny sytuacji finansowej, rzeczywista ocena wypłacalności finansowej przedsiębiorstwa, integracja z całym systemem zarządzania, orientacja na realizację strategicznych celów przedsiębiorstwa, opracowywanie i wykorzystywanie narzędzi jakościowych do podejmowania decyzji finansowych w obliczu niepewności i ryzyka.

Słowa kluczowe: równowaga finansowa, stabilność finansowa, finansowanie przedsiębiorstwa, mechanizm zapewniania stabilności finansowej, ryzyko, niepewność.

JEL Codes: O13, O16

Information about the authors:

prof. Nadiia Davydenko,

National University of Life and Environmental Sciences of Ukraine, Faculty of

Economics, Department of Finance str. Heroiv Oborony, 10, 03-041 Kyiv, Ukraine

e-mail: davidenk@ukr.net

ORCID: 0000-0001-7469-5536 
dr hab. Natalia Wasilewska, prof. UJK

Jan Kochanowski University in Kielce, Faculty of Law and Social Sciences,

Department of Economics and Finance

str.Uniwersytecka 15, 25-406 Kielce

e-mail: nwasilewska@ujk.edu.pl

ORCID:0000-0001-8638-473 